\title{
New Developments in Prokinetic Therapy for Gastric Motility Disorders
}

\author{
Michael Camilleri * and Jessica Atieh \\ Clinical Enteric Neuroscience Translational and Epidemiological Research (CENTER), Division of Gastroenterology and \\ Hepatology, Mayo Clinic, Rochester, MN, United States
}

\section{OPEN ACCESS}

Edited by:

Jan Tack,

University Hospitals Leuven, Belgium

Reviewed by:

Duygu Ağagündüz,

Gazi University, Turkey

Carmelo Scarpignato, University of Parma, Italy

*Correspondence:

Michael Camiller

camilleri.michael@mayo.edu

Specialty section: This article was submitted to Gastrointestinal and Hepatic Pharmacology,

a section of the journal Frontiers in Pharmacology

Received: 18 May 2021 Accepted: 10 August 2021 Published: 24 August 2021

Citation: Camilleri M and Atieh J (2021) New Developments in Prokinetic Therapy for Gastric Motility Disorders. Front. Pharmacol. 12:711500. doi: 10.3389/fphar.2021.711500
Prokinetic agents amplify and coordinate the gastrointestinal muscular contractions to facilitate the transit of intra-luminal content. Following the institution of dietary recommendations, prokinetics are the first medications whose goal is to improve gastric emptying and relieve symptoms of gastroparesis. The recommended use of metoclopramide, the only currently approved medication for gastroparesis in the United States, is for a duration of less than 3 months, due to the risk of reversible or irreversible extrapyramidal tremors. Domperidone, a dopamine D2 receptor antagonist, is available for prescription through the FDA's program for Expanded Access to Investigational Drugs. Macrolides are used off label and are associated with tachyphylaxis and variable duration of efficacy. Aprepitant relieves some symptoms of gastroparesis. There are newer agents in the pipeline targeting diverse gastric (fundic, antral and pyloric) motor functions, including novel serotonergic 5- $\mathrm{HT}_{4}$ agonists, dopaminergic $\mathrm{D}_{2 / 3}$ antagonists, neurokinin $\mathrm{NK}_{1}$ antagonists, and ghrelin agonist. Novel targets with potential to improve gastric motor functions include the pylorus, macrophage/ inflammatory function, oxidative stress, and neurogenesis. In the current review, we discuss the use of pharmacological approaches with potential to enhance motor functions in the management of gastroparesis.

Keywords: aprepitant, domperidone, erythromycin, functional dyspepsia, gastroparesis, ghrelin, prucalopride, relamorelin

\section{INTRODUCTION: DEFINITIONS AND CURRENTLY AVAILABLE PROKINETIC TREATMENTS}

Gastroparesis is characterized by upper gastrointestinal symptoms including nausea, vomiting, early satiety, postprandial fullness, bloating, and upper abdominal pain, as well as slow gastric emptying of solids in the absence of gastric outlet or intestinal obstruction. In clinical practice, the most common etiologies of gastroparesis are diabetes mellitus, idiopathic, iatrogenic (post-surgical or medication), diseases affecting the neural control arising in the brain and spinal cord (such as Parkinson disease, which may also be associated with effects of dopaminergic agents), and diseases that damage intrinsic nerves or smooth muscle, often as a result of tissue infiltration (such as scleroderma) or muscle degeneration (as in amyloidosis).

Prokinetic agents are medications that amplify and coordinate gastrointestinal muscular contractions (Acosta and Camilleri, 2015), including coordination between different segments of the gut, thereby enhancing propulsion of intra-luminal contents. Some prokinetics are active in selective areas of the gastrointestinal tract, whereas the activity of other prokinetics is more generalized and reflects the location of receptor targets of the pharmacological agents. In 
the current review, we discuss the use of prokinetics in the management of gastric motility disorders.

In most countries, only two medications are approved or available for the treatment of gastroparesis: metoclopramide and domperidone. Both agents are antagonists at dopamine-2 $\left(D_{2}\right)$ receptors. The effect of the endogenous transmitter, dopamine, is to inhibit the release of acetylcholine (ACh), and this results in decrease in motility of the stomach and proximal small bowel (Tonini et al., 2004). These inhibitory effects of endogenous dopamine are reversed by D2 receptor antagonists. In general, metoclopramide and domperidone were equally effective for relief of symptoms, although central nervous system adverse effects were more common with metoclopramide (Patterson et al., 1999; Camilleri et al., 2013). Current guidelines recommend liquid formulation metoclopramide, 5 to $10 \mathrm{mg}$ orally, $30 \mathrm{~min}$ before meals and at bedtime in patients with gastroparesis. Higher doses are not recommended in order to avoid side effects. A new intra-nasal formulation of metoclopramide has also been approved by the Food and Drug Administration (FDA) of the United States.

Domperidone is available for physician prescription through FDA's program for Expanded Access to Investigational Drugs (https://www.fda.gov/drugs/investigational-new-drugind-application/how-request-domperidone-expanded-access-use). The recommended starting dose of domperidone is $10 \mathrm{mg}$, t.i.d., which could be increased (if necessary) to $20 \mathrm{mg}$, t.i.d., and at bedtime. Domperidone has been associated with cardiac dysrhythmias which led to its removal in Europe from the over-the-counter space to availability only by prescription. It is generally recommended that domperidone be avoided if the corrected QTc interval on the patient's electrocardiogram is $>$ $470 \mathrm{~ms}$ in males and $>450 \mathrm{~ms}$ in females.

An off-label prokinetic approach for gastroparesis involves the use of inhibitors of acetyl cholinesterase. Neostigmine is a shortacting agent that was shown to accelerate gastric emptying of liquids in patients who are critically ill and have delayed gastric emptying; this was associated with induction of an irregular increase in gastric and duodenal contractility (Bortolotti et al., 1995; Lucey et al., 2003). Neostigmine has a short duration of action, is administered parenterally by slow intravenous or intramuscular injection. Therefore, its use is limited to the hospital setting with electrocardiogram monitoring because of the potential to induce vagotonia and bradycardia.

Pyridostigmine has a longer duration of action; it is not approved for treatment of gastroparesis; it is available in liquid or tablet formulation and, based on clinical experience, it is used at doses up to $60 \mathrm{mg}$, t.i.d. There are, as yet, no clinical trials documenting its clinical efficacy in gastroparesis. In an open-label case series, pyridostigmine was beneficial in relief of symptoms in children with such upper gastrointestinal motility problems as chronic intestinal pseudo-obstruction, delayed small bowel transit accompanying gastroparesis, and chronic constipation associated with failure to thrive. Effective dosing ranged between 0.25 and $2.0 \mathrm{mg} / \mathrm{kg} /$ day (Manini et al., 2017).

The serotonergic $5-\mathrm{HT}_{4}$ receptor agonist, cisapride, was associated with symptomatic benefit in patients with gastroparesis based on short-or medium-term placebo-controlled trials
(Corinaldesi et al., 1987; Camilleri et al., 1989; Richards et al., 1993a), and on long-term, open-label studies (Abell et al., 1991). Although cisapride accelerated gastric emptying, it did not necessarily enhance glycemic control, over the long-term (Braden et al., 2002). Cisapride is no longer available in most countries due to withdrawal as a result of cardiovascular concerns (cardiac arrhythmias due to inhibition of the human ether-à-go-go-related gene $[\mathrm{hERG}]$ potassium channel).

Other medications available in a few countries, clebopride, cinitapride, and mosapride, are not reviewed in detail here in view of the relatively weak evidence of efficacy in gastroparesis. There are no controlled trials of clebopride (D2 antagonist) in gastroparesis other than in dyspepsia with radiologically delayed gastric emptying, a criterion not currently accepted for gastroparesis (Bavestrello et al., 1985). Cinitapride (a $5-\mathrm{HT}_{1}$ and $5-\mathrm{HT}_{4}$ agonist and $5-\mathrm{HT}_{2}$ antagonist) was superior to placebo in a parallel design study of 19 patients with dyspepsia associated with postprandial distress and mildly to moderately delayed gastric emptying (Portincasa et al., 2009). Mosapride (a 5- $\mathrm{HT}_{4}$ agonist) enhanced gastric emptying in gastroparesis associated with treatment with interferon, but had no significant effects on symptoms (Kawamura et al., 2012).

There is, therefore, significant and unmet clinical need to develop new prokinetic agents for gastric motility disorders. Over the past few years, it has been appreciated that the upper gastrointestinal symptoms that are consistent with gastroparesis may arise from diverse gastric motor dysfunctions that constitute potential targets for pharmacological agents, thus, expanding the spectrum of therapeutic approaches.

\section{Gastric Motor Dysfunctions}

There are three dominant motor dysfunctions that can result in diverse manifestations or symptoms: gastric emptying, gastric accommodation, and pyloric dysfunction. It is relevant to note that, in patients with upper gastrointestinal symptoms, there are about $25 \%$ of patients with delayed gastric emptying, about $25 \%$ with impaired gastric accommodation, and about $25 \%$ with the combination of both gastric motor dysfunctions (Park et al., 2017; Chedid et al., 2019a). In addition, among patients with gastroparesis, a subset of those with antral hypomotility also has evidence of pylorospasm (Mearin et al., 1986).

In this article, new developments in prokinetic therapy for these motility disorders are reviewed. Prior to exploring the pharmacological approaches using prokinetics, it is useful to review the overall principles regarding the methods used to measure those gastric motor functions as they are used in pharmacodynamic assessment of the therapeutic approaches.

Identification of disorders of gastric emptying requires an accurate gastric emptying test. The optimal gastric emptying diagnostic tests typically involve measurements at standard times (e.g., 0, 0.5, 1, 2, 3, and $4 \mathrm{~h}$ ) over 4 -h by scintigraphy or by stable isotope breath tests. The symptoms associated with retardation of gastric emptying are nausea, vomiting, and upper abdominal bloating, but pain is not a quintessential symptom of delayed gastric emptying. A significant relationship has been demonstrated between the acceleration of gastric emptying and the improvement of symptoms. Thus, using a meta-regression analysis, it was demonstrated that acceleration in 
gastric emptying $\mathrm{T}_{1 / 2}$ of $20.4 \mathrm{~min}$ was associated with al-unit reduction in the severity of symptoms. This analysis was based on standardized mean difference in order to account for differences in the measurements of symptoms between studies (Vijayvargiya et al., 2019). Normal values and performance characteristics of the scintigraphic test have been published (Szarka et al., 2008; Camilleri et al., 2012). Disorders of gastric emptying can be ameliorated by targeting specific receptors, including serotonergic $5-\mathrm{HT}_{4}$, dopamine $\mathrm{D}_{2 / 3}$, and neurokinin $\mathrm{NK}_{1}$ receptors.

Disorders of gastric accommodation are typically associated with postprandial distress syndrome, a component of functional dyspepsia. In fact, approaches to enhance postprandial accommodation have been associated with reduced symptoms of functional dyspepsia, for example, by using the serotonergic 5$\mathrm{HT}_{1 \mathrm{~A}}$ agonist, buspirone, or by using acotiamide, an antagonist of acetylcholinesterase and antagonist of presynaptic $M_{1}$ and $M_{2}$ muscarinic receptors. These muscarinic receptors are involved in inhibition of acetylcholine release. Therefore, by antagonizing those receptors and by inhibiting acetylcholinesterase, acotiamide leads to an increased local level of acetylcholine, which is an excitatory transmitter in the enteric nervous system and parasympathetic nerve pathways.

There are currently three direct and one indirect measurements of gastric accommodation. The three direct methods are: first, singlephoton emission computerized tomography (SPECT) imaging (Bouras et al., 2002), second, measurement of proximal gastric volume by barostat, whereby the pressure of air within an infinitely compliant polyethylene balloon is clamped (maintained constant by an electronic pump aspirating or infusing air), and the continuous monitoring of the intra-balloon volume provides a measurement of gastric tone. A third method is intraluminal high resolution manometry in the proximal stomach (Tack et al., 1998; Carbone et al., 2017). In addition, an indirect measurement of gastric accommodation can be obtained through ingestion of a nutrient drink at constant rate until the maximum tolerated volume (MTV) is reached]; this measurement assesses gastric sensation (Tack et al., 2003). However, in addition, it provides an indirect measure of accommodation if the MTV is less than $\sim 750$ kilocalories, since there is a linear correlation between the MTV and gastric accommodation volume measured by a barostat when the MTV is below $750 \mathrm{kcal}$ (Tack et al., 2003). There have been attempts to use two-dimensional imaging of the area of the proximal stomach immediately after food ingestion to estimate gastric accommodation; however, these measurements were subsequently found to be inaccurate relative to three-dimensional imaging and the 2-D imaging method therefore requires further validation (Orthey et al., 2018a; Orthey et al., 2018b; Chedid et al., 2019b).

Disorders of pyloric function are difficult to assess noninvasively and two approaches are available, requiring intraluminal measurements. These are antropyloroduodenal manometry and the Endoflip (endoscopic functional lumen imaging probe) device. The former uses closely-spaced manometric sensors to measure the pressure profile and identifies pyloric activity by the combination of phasic and tonic contractions, as well as the combination of antral and duodenal phasic pressure activity in the manometric tracing (Nelson et al., 2016). The Endoflip device is a longer $(8$ or $16 \mathrm{~cm})$ probe consisting of 16 paired impedance planimetry electrodes mounted on a catheter and located within a balloon that is filled with a conductive fluid (typically distended with 40-50 ml fluid); excitation electrodes at either end of the balloon generate a low electric current. The impedance electrodes measure voltage and, using the voltages, the device calculates the crosssectional areas (CSA) using Ohm's Law (resistance = voltage/ current) at each electrode interval. A solid-state pressure transducer is located at the distal end of the balloon. Thus, by measuring the pressure simultaneously with the CSA, it is possible to calculate a distensibility index (Vosoughi et al., 2020).

\section{Novel Pharmacotherapies: Current State of Evidence}

Symptoms may result from diverse pathophysiological disorders including accelerated or slow emptying, reduced gastric accommodation, gastric dysrhythmias, or duodenal mechanisms. It has therefore been proposed that future treatment of gastric motor dysfunctions and related symptoms should be based on identified pathophysiology or "actionable biomarkers" that is putative mechanisms that are associated with induction of the symptoms suggesting gastroparesis and that can be normalized with specific treatments, such as treatments targeting5- $\mathrm{HT}_{4}$, dopamine $\mathrm{D}_{2}$ and $\mathrm{D}_{3}$, and $\mathrm{NK}_{1}$ receptors. The available and investigational prokinetic agents discussed below for gastric motility disorders are summarized in Table $\mathbf{1 .}$

\section{Novel 5- $\mathrm{HT}_{4}$ Receptor Agonists Targeting Gastric Emptying}

Several "new generation" $5-\mathrm{HT}_{4}$ receptor agonists are selective for 5- $\mathrm{HT}_{4}$ receptors withouthERG effects (De Maeyer et al., 2006; Tack et al., 2012); these include prucalopride, velusetrag, naronapride, and felcisetrag.

Prucalopride is approved by the European Medicines Agency (EMA) and the FDA for the treatment of chronic constipation. In a randomized, placebo-controlled, cross-over study involving 34 patients (28 idiopathic, six diabetic) with gastroparesis, patients received prucalopride, $2 \mathrm{mg}$ once daily, or placebo for 4 weeks, with a 2-weeks washout between treatments. Prucalopride was efficacious in relieving symptoms based on total Gastroparesis Cardinal Symptom Index, subscales of nausea/vomiting, fullness/ satiety, and bloating/distention, as well as improvement in the overall Patient Assessment of Upper Gastrointestinal DisordersQuality of Life score (Carbone et al., 2019). Similarly, velusetrag, was reported to be efficacious in the treatment of diabetic and idiopathic gastroparesis (Kuo et al., 2021a).

Intravenously administered felcisetrag significantly accelerated gastric emptying, small bowel transit and colonic transit compared to placebo in patients with gastroparesis with previously confirmed delayed gastric emptying. Felcisetrag was well tolerated (Chedid et al., 2021). In a previous double-dummy, parallel-group, randomized trial, felcisetrag (TAK-954), administered to mechanically ventilated patients with enteral feeding intolerance defined as gastric residual volume $\geq 200 \mathrm{ml}$, led to a greater proportion of patients with normal gastric retention compared to four doses of $10 \mathrm{mg}$ metoclopramide (Chapman et al., 2021). 
TABLE 1 | Current and investigational prokinetic drugs for gastric motility disorders.

\begin{tabular}{|c|c|c|c|c|}
\hline Drug name & Disease & $\begin{array}{l}\text { Effect on gastric } \\
\text { motor function }\end{array}$ & $\begin{array}{l}\text { GP } \\
\text { symptoms }\end{array}$ & Ref. \# \\
\hline \multicolumn{5}{|c|}{ 5-HT4 receptor agonist } \\
\hline Prucalopride & IG and DG & $\uparrow \mathrm{GE}$ & Improved & Carbone et al. (2019) \\
\hline Velusetrag & IG and DG & $\uparrow \mathrm{GE}$ & Improved & Kuo et al. (2021a) \\
\hline Felcisetrag & $I G$ and $D G$ & $\uparrow \mathrm{GE}$ & Not studied & (Chapman et al., 2021; Chedid et al., 2021) \\
\hline Tegaserod & FD & $\uparrow \mathrm{GA}$ & Mixed effects & (Vakil et al., 2008; Tack et al., 2010) \\
\hline \multicolumn{5}{|c|}{ D2/3 receptor antagonist } \\
\hline Trazpiroben & $I G$ and $D G$ & $\uparrow$ volume to fullness, No $\Delta$ in GE & Improved & Kuo et al. (2021b) \\
\hline \multicolumn{5}{|c|}{ Ghrelin receptor agonist } \\
\hline Relamorelin & $\mathrm{DG}$ & $\uparrow \mathrm{GE}, \uparrow$ antral contractions & Improved & $\begin{array}{l}\text { (Shin et al., 2013a; Shin et al., 2013b; } \\
\text { Lembo et al., 2016; Nelson et al., 2016; Camilleri et al., } \\
\text { 2017; Camilleri et al., 2020) }\end{array}$ \\
\hline \multicolumn{5}{|c|}{ Muscarinic $M 1 / 2$ receptor antagonist } \\
\hline Acotiamide & FD & $\uparrow \mathrm{GE}$ and $\mathrm{GA}$ & Improved & Kusunoki et al. (2012) \\
\hline \multicolumn{5}{|c|}{ Motilin receptor agonist } \\
\hline Erythromycin & IG and DG & $\begin{array}{l}\uparrow \mathrm{GE}, \uparrow \text { fundic and antral contractions, } \downarrow \\
\text { pyloric contractions }\end{array}$ & Improved & $\begin{array}{l}\text { (Janssens et al., 1990; Catnach and } \\
\text { Fairclough, 1992; Richards et al., 1993b; Parkman et al., } \\
\text { 1995) }\end{array}$ \\
\hline Azithromycin & Gastroparesis & $\uparrow \mathrm{GE}$ & Not studied & Larson et al. (2010) \\
\hline Clarithromycin & FD & $\uparrow \mathrm{GE}$ & Not studied & Bortolotti et al. (1999) \\
\hline \multicolumn{5}{|c|}{ NK1 receptor agonist } \\
\hline Aprepitant & IG and DG & $\uparrow \mathrm{GA}$, No $\Delta$ in GE & Improved & (Jacob et al., 2017; Pasricha et al., 2018) \\
\hline Tradipitant & $I G$ and $D G$ & Not studied & Improved & Carlin et al. (2021) \\
\hline \multicolumn{5}{|c|}{ Opioid antagonists [non-selective (NS) or peripherally active (PAMORA)] } \\
\hline Naloxone [NS] & $F D$ and IG & No $\Delta$ in GE & Not studied & Narducci et al. (1986) \\
\hline MNTX [PAMORA] & $\begin{array}{l}\text { opioid-induced gastric } \\
\text { delay }\end{array}$ & No $\Delta$ in GE & Not studied & Wong et al. (2010) \\
\hline $\begin{array}{l}\text { Naloxegol } \\
\text { [PAMORA] }\end{array}$ & $\begin{array}{l}\text { opioid-induced gastric } \\
\text { delay }\end{array}$ & No $\Delta$ in GE & Not studied & Halawi et al. (2018) \\
\hline \multicolumn{5}{|c|}{ Phosphodiesterase-5 Inhibitor } \\
\hline Sildenafil & $\begin{array}{l}\text { Gastroparesis with } \\
\text { uremia }\end{array}$ & No $\Delta$ in GE & Not studied & Dishy et al. (2004) \\
\hline
\end{tabular}

Abbreviations: DG, diabetic gastroparesis; FD, functional dyspepsia; GA, gastric accommodation; GE, gastric emptying; GP, gastroparesis; IG, idiopathic gastroparesis; MNTX, methylnaltrexone; PAMORA, peripherally active $\mu$-opioid receptor antagonist.

Velusetrag and felcisetrag (TAK-954) had no significant effects on coronary tone (demonstrated in dog, pig or human coronary arteries) or cardiac rhythm (hERG channel potassium conductance) or platelet function), or other off-target actions (Beattie et al., 2013). Felcisetrag has high affinity $(\mathrm{pK}(\mathrm{i})=9.4)$ for human recombinant $5-\mathrm{HT}_{4 \mathrm{c}}$ receptors and $>2,000$-fold selectivity for those receptors compared to 78 other receptors (including all other 5-HT receptors, several non-5HT receptors), transporters or ion channels tested (Beattie et al., 2011).

Another potential mechanism to enhance neuromuscular function in the stomach is an anti-inflammatory effect that may facilitate vagal stimulation. This has been demonstrated with the $5-\mathrm{HT}_{4}$ agonist, prucalopride, which modified responses of T2helper cells and shortened post-operative ileus (Matteoli et al., 2013; Bosmans et al., 2017; Stakenborg et al., 2019). There is evidence that macrophages that are not derived from circulating monocytes, are resident in the gut, are distinct from CD206 (also called M2) macrophages, and can impact enteric nervous system function (De Schepper et al., 2018). This anti-inflammatory mechanism may be relevant since some animal models have inflammation and oxidative stress-induced damage to the enteric nervous system and pacemaker cells (discussed below).

\section{Targeting Sensations With $D_{2} / D_{3}$ and $N_{1}$ Antagonists}

For upper gastrointestinal disorders associated with increased gastric sensation, such as functional dyspepsia, the dopaminergic $\mathrm{D}_{2} / 3$ 


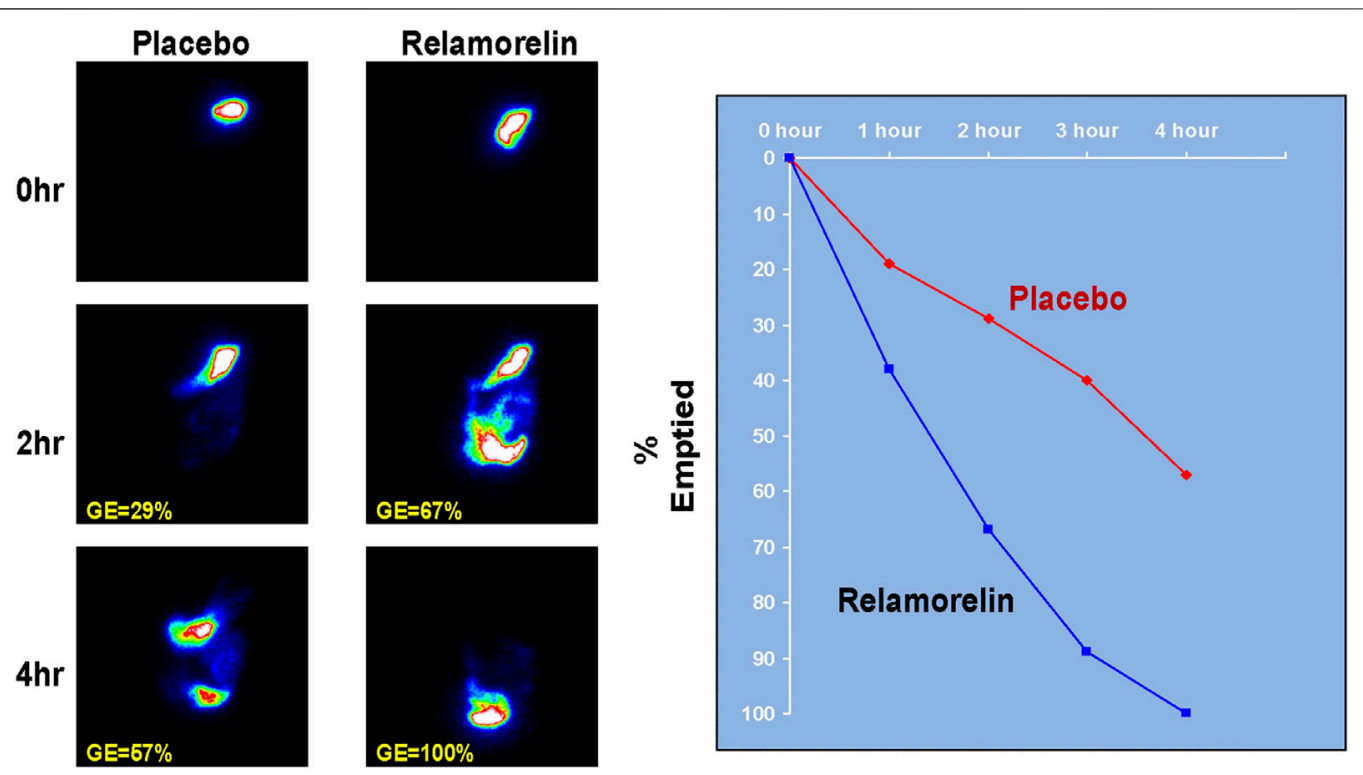

FIGURE 1 | Effect of relamorelin on gastric emptying in a patient with type 1 diabetes with gastroparesis. Aadapted from ref. 51 , Shin A, et al. Clin Gastroenterol Hepatol 2013; 11:1,453-1,459.

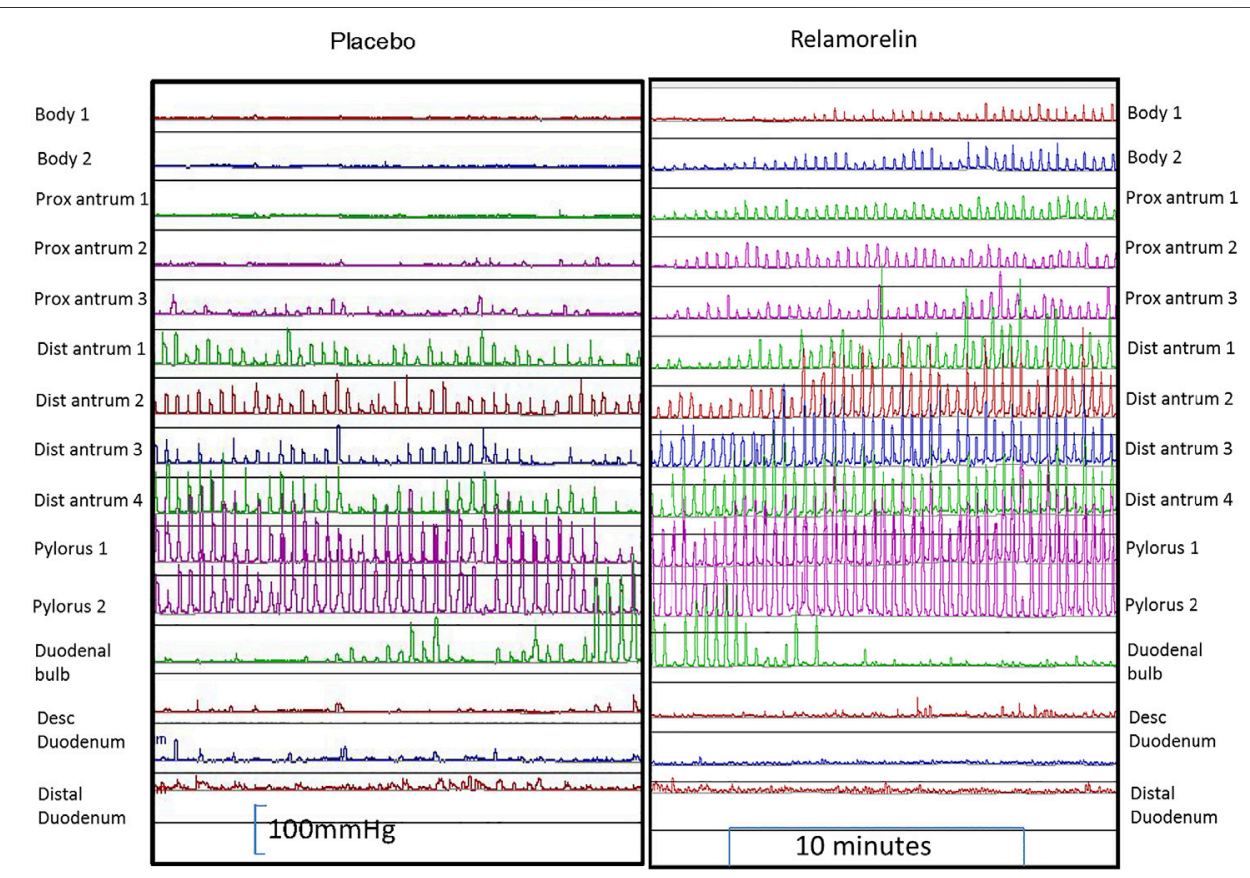

FIGURE 2 | Effect of relamorelin on antral motility in a healthy subject. Reproduced with permission from ref. 29, Nelson A, Camilleri M, et al. Neurogastroenterol Motil 2016; 28:1,705-1,713.

antagonist, trazpiroben (TAK-506) administered for 1 week significantly increased the volume to fullness during a nutrient drink test, compared to baseline (Kuo et al., 2021b). Moreover, in a placebo-controlled trial, the $\mathrm{NK}_{1}$ receptor antagonist, aprepitant, improved multiple symptoms of gastroparesis including nausea (Pasricha et al., 2018). These beneficial effects may reflect the known effects of NK1 receptor antagonists on the vomiting center in the brainstem, akin to the action associated with reduced chemotherapy-induced emesis. Another potential mechanism for the symptomatic benefit may be related to increased fasting and accommodation volumes of the stomach without deleterious effect on gastric emptying, which has been demonstrated in healthy controls (Jacob et al., 2017). The novel $\mathrm{NK}_{1}$ receptor antagonist, tradipitant, improved several symptoms of gastroparesis in a 4-weeks, randomized, controlled trial (Carlin et al., 2021). The symptomatic benefit 
was most marked in patients with vomiting among the baseline symptoms; it was interesting to note that improvement of nausea was associated with improvement of all the other symptoms evaluated.

\section{Ghrelin Receptor Agonist}

Ghrelin is predominantly located in the stomach. It is an appetitestimulating 28 amino acid hormone. Administration of a pharmacological dose of recombinant human ghrelin increased proximal gastric tone through central and peripheral effects (Peeters, 2003; Tack et al., 2006), and in some studies, it also accelerated stomach emptying in patients with gastroparesis [reviewed in ref. (Camilleri et al., 2009).].

A synthetic pentapeptide ghrelin receptor agonist, relamorelin, is 15-130 times more potent than natural ghrelin (Van der Ploeg et al., 2014). At a dose of $100 \mathrm{mg}$ subcutaneously (s.c.), relamorelin accelerated gastric emptying of solids Figure $\mathbf{1}$ in patients with either type 1 or type 2 diabetes mellitus with prior documentation of delayed gastric emptying (Shin et al., 2013a; Shin et al., 2013b). Relamorelin also increased distal antral contraction frequency without impeding gastric accommodation or altering postprandial satiation in healthy volunteers Figure 2 (Nelson et al., 2016), which differentiates its effects from those of the macrolide antibiotic, erythromycin. In phase $2 \mathrm{~A}$ and $2 \mathrm{~B}$, randomized, controlled trials in patients with diabetic gastroparesis, relamorelin improved clinical symptoms and appears to be safe, other than the induction of (typically postprandial) hyperglycemia which is attributable to the acceleration of gastric emptying (Lembo et al., 2016; Camilleri et al., 2017; Camilleri et al., 2020). It has therefore been recommended that proactive steps should be taken to control postprandial glycemia in diabetics receiving relamorelin (Camilleri et al., 2020).

\section{Motilin Receptor Agonists}

The most common motilin receptor agonists are the macrolide antibiotics that stimulate gastrointestinal motilin receptors, especially gastric receptors. Erythromycin improves gastric emptying and transiently improves symptoms before there is downregulation of the motilin receptor, typically in about 4 weeks after onset of therapy (Richards et al., 1993b; Thielemans et al., 2005), manifesting as tachyphylaxis or reduced treatment efficacy. One of the attractions of erythromycin is that it stimulates fundic and antral contractions, while inhibiting pyloric contractility (Janssens et al., 1990; Catnach and Fairclough, 1992; Parkman et al., 1995). The current recommended dose for hospitalized patients with gastroparesis is $1.5-3 \mathrm{mg} / \mathrm{kg}$ (by i.v. infusion over $45 \mathrm{~min}$ ) every $6-8 \mathrm{~h}$, and $125 \mathrm{mg}$ b.i.d., orally for outpatient gastroparesis management for a few weeks. The liquid formulation is often preferred in order to enhance pharmacokinetics in patients with marked delay in gastric emptying. Side effects experienced with erythromycin treatment include abdominal pain, nausea, and diarrhea. Caution should be taken when erythromycin is co-administered with agents that alter or are metabolized by cytochrome P450 (CYP) 3A4 (e.g., diltiazem or verapamil or domperidone) because the drug interactions may be associated with risk for sudden cardiac death (Ray et al., 2004).

Azithromycin and clarithromycin are other macrolides that accelerate gastric emptying (Bortolotti et al., 1999; Larson et al.,
2010). There are no randomized, placebo-controlled trials to assess efficacy. Use of these agents should be balanced with the potential of tachyphylaxis due to downregulation of the target receptors, cardiac risk as mentioned above, or development of bacterial resistance to these useful antimicrobial agents.

\section{Targeting the Gastric Fundus}

Mechanistic studies showed that acotiamide enhanced gastric accommodation and gastric emptying of a liquid meal (Kusunoki et al., 2012) and improved symptoms in patients with functional dyspepsia (Matsueda et al., 2012). Some 5- $\mathrm{HT}_{4}$ receptor agonists also enhance gastric accommodation, such as tegaserod in dyspeptics with normal gastric emptying (Tack et al., 2010). This provides a rationale for their use in functional dyspepsia. However, two randomized controlled trials that studied tegaserod in patients with functional dyspepsia demonstrated mixed effects on dyspepsia symptoms (Vakil et al., 2008).

Recent data using simultaneous measurement of gastric accommodation and emptying of a solid egg meal suggests that there is a direct relationship between the degree of gastric accommodation and the gastric emptying lag duration and $T_{1 / 2}$, suggesting that, in some patients, impaired emptying may result from excessive gastric accommodation with delayed movement of solid food from the fundus to the antrum of the stomach (Wang et al., 2021). This observation suggests that stimulation of the proximal stomach with reduced gastric accommodation may actually enhance gastric emptying in patients with gastroparesis.

It is not surprising, therefore, that erythromycin is associated with marked acceleration or dumping of food from the stomach since, as a motilin receptor agonist and stimulant of cholinergic mechanisms, it enhances both fundic contraction as well as antral motor function, thereby having a dual effect on mechanisms associated with increased longitudinal axial forces in the antrum in healthy participants and patients with dysmotilities and acceleration of gastric emptying (Surrenti et al., 1996; Coulie et al., 1998; Liau et al., 2001). Further studies on the potential of fundic and antral stimulants to improve gastric symptoms would be of considerable interest.

\section{Targeting the Pylorus}

It is increasingly recognized that patients on long-term opioid medications may present with gastroparesis (Hasler et al., 2019). The mechanisms associated with the effects of opiates or opioid medications are reviewed elsewhere (Camilleri and Sanders, 2020). Opioids can induce pyloric dysfunction in addition to inhibition of antral motor function, both of which contribute to delayed gastric emptying. It is, therefore, relevant to assess whether targeting the pylorus or inhibiting the effects of opioids might be a therapeutic approach for gastric emptying delay attributed in part to pyloric dysfunction.

Although the classical pharmacological approach to treating the pylorus in gastroparesis involves botulinum toxin injection and there is open-label experience to suggest efficacy especially with higher dose injections (Coleski et al., 2009), two placebocontrolled trials did not demonstrate efficacy (Arts et al., 2007; Friedenberg et al., 2008).

Two pharmacological approaches have been pursued to reverse pyloric dysfunction in gastroparesis. One approach is 
the use of sildenafil (Watkins et al., 2000), a phosphodiesterase-5 inhibitor which mimics the effect of nitric oxide by increasing intracellular cGMP. A reduced expression of neuronal nitric oxide synthase in the pylorus of diabetic mice was reversed by treatment with insulin and by sildenafil. However, in gastroparesis associated with uremia, there was no significant effect of sildenafil on gastric emptying (Dishy et al., 2004).

A second approach to reverse pyloric contractility involves use of opioid antagonists. In an older study, naloxone did not stimulate gastric emptying in healthy subjects or in patients with gastric hypomotility associated with functional dyspepsia or idiopathic gastroparesis (Narducci et al., 1986). Two studies have tested the potential of peripherally active $\mu$-opioid receptor antagonists (PAMORA) in the setting of codeine-induced delay in gastric emptying in opioid-naïve healthy participants. At the doses approved for treatment of chronic opioid-induced constipation (OIC), short-term administration of methylnaltrexone (s.c. $0.30 \mathrm{mg} / \mathrm{kg})$ or naloxegol $(25 \mathrm{mg})$ daily did not inhibit the retardation of gastric emptying induced by codeine in healthy, opioid-naïve volunteers (Wong et al., 2010; Halawi et al., 2018).

As stated above, there is evidence of pyloric relaxation by erythromycin by stimulating the inhibitory nerves of the pylorus; however, the long-term effects of erythromycin on the pylorus are unclear and they have not been studied extensively.

\section{Targeting $\mathbf{M}_{2}$ Macrophages and Oxidative Stress}

Gastroparesis may also result from abnormal function of enteric mechanisms which may be targeted by macrophage-based immune dysregulation, as demonstrated in diabetic mice with delayed gastric emptying (Cipriani et al., 2018). Reduced pacemaker cells [interstitial cells of Cajal (ICCs), and plateletderived growth factor receptor alpha (PDGFRa) fibroblast-like cells] and numbers of nitrergic neurons and CD206 positive macrophages have been reported in some studies in patients with idiopathic or diabetic gastroparesis (Grover et al., 2011; Grover et al., 2012; Grover et al., 2017), though the ICC results were not confirmed in patients with idiopathic gastroparesis (Bernard et al., 2014; Herring et al., 2018). Damage to the pacemaker cells may occur because of depletion of antiinflammatory resident $\mathrm{M}_{2}$ macrophages expressing heme oxygenase-1 $\left(\mathrm{HO}_{1}\right)$, allowing oxidative stress to damage the pacemaker cells or enteric nerves, as evidenced from animal models of gastroparesis (Choi et al., 2008; Cipriani et al., 2018). However, hemin, an heme oxygenase $\left(\mathrm{HO}_{1}\right)$ inhibitor, failed to reverse delayed gastric emptying in a randomized, controlled trial in humans. Unfortunately, the pharmacokinetics of the hemin in that trial were insufficient to conclusively test whether countering oxidative stress can restore normal ENS function and gastric emptying (Bharucha et al., 2016).

\section{Potential Pharmacological Promotion of Neuronal Cell Differentiation}

As in other tissues, there is a dynamic balance in the enteric nervous system between cell loss by apoptosis, phagocytosis of dead cells by resident macrophages, and restoration of new cells from stem cells. Similarly, in the enteric nervous system, the loss of neurons is replenished by neurogenesis precursor cells that behave like stem cells and are prominent in the submucosal zone and in the muscular layers (Kulkarni et al., 2017). It has been shown, in vitro, that a selective estrogen receptor $\beta$ (ER $\beta$ ) agonist, LY3201, stimulated glialto-neuron cell differentiation. It also increased recovery of neurons in the damaged myenteric plexus in two in vivo models of enteric neuronal damage in mice, specifically the damage resulting from administration of a high-fat diet, or the serosal application of the cationic detergent, benzalkonium chloride (D'Errico et al., 2018).

The potential for neurogenesis and nerve growth factors to restore normal propulsion has been demonstrated in both animal and human studies. In rats, exogenous brain-derived neurotrophic factor (BDNF) increased myoelectric activity and peristalsis in the gastrointestinal tract and colon (Chai et al., 2003; Grider et al., 2006). In addition, exogenous recombinant human BDNF and neurotrophin-3 were shown to accelerate gastrointestinal and colonic transit in healthy human volunteers and in patients with constipation respectively (Coulie et al., 2000). Thus, neurogenesis has the potential to improve enteric nervous system function in patients with gastroparesis.

\section{CONCLUSION}

There has been extensive research into the effects of diverse classes of medications targeting different pathophysiological mechanisms including defective contraction or coordination of the stomach manifesting with symptoms and objective retardation of gastric emptying. The findings reported augur well for the development of effective treatments for gastroparesis. These include immune (such as macrophage) modulation, reversal of oxidative stress, direct pharmacological therapies targeting pivotal receptors without inducing adverse effects, and endoscopic pyloromyotomy. Further validation studies and approval by regulatory agencies should lead to opportunities to resolve the significant unmet clinical need in patients with gastroparesis.

\section{AUTHOR CONTRIBUTIONS}

MC-conceptual study design, literature review, drafting, revising and finalizing the article JA-literature review, revising and finalizing the article.

\section{FUNDING}

MC is supported by grant R01-DK122280 from National Institutes of Health. He has received single-center research grants from Takeda to study TAK-954 and from Vanda to study tradipitant.

\section{ACKNOWLEDGMENTS}

The authors thank Cindy Stanislav for excellent secretarial assistance. 


\section{REFERENCES}

Abell, T. L., Camilleri, M., DiMagno, E. P., Hench, V. S., Zinsmeister, A. R., and Malagelada, J. R. (1991). Long-term Efficacy of Oral Cisapride in Symptomatic Upper Gut Dysmotility. Dig. Dis. Sci. 36 (5), 616-620. doi:10.1007/bf01297028

Acosta, A., and Camilleri, M. (2015). Prokinetics in Gastroparesis. Gastroenterol. Clin. North. Am. 44 (1), 97-111. doi:10.1016/j.gtc.2014.11.008

Arts, J., Holvoet, L., Caenepeel, P., Bisschops, R., Sifrim, D., Verbeke, K., et al. (2007). Clinical Trial: a Randomized-Controlled Crossover Study of Intrapyloric Injection of Botulinum Toxin in Gastroparesis. Aliment. Pharmacol. Ther. 26 (9), 1251-1258. doi:10.1111/j.1365-2036.2007.03467.x

Bavestrello, L., Caimi, L., and Barbera, A. (1985). A Double-Blind Comparison of Clebopride and Placebo in Dyspepsia Secondary to Delayed Gastric Emptying. Clin. Ther. 7 (4), 468-473.

Beattie, D. T., Armstrong, S. R., Vickery, R. G., Tsuruda, P. R., Campbell, C. B., Richardson, C., et al. (2011). The Pharmacology of TD-8954, a Potent and Selective 5-HT(4) Receptor Agonist with Gastrointestinal Prokinetic Properties. Front. Pharmacol. 2, 25. doi:10.3389/fphar.2011.00025

Beattie, D. T., Higgins, D. L., Ero, M. P., Amagasu, S. M., Vickery, R. G., Kersey, K., et al. (2013). An In Vitro Investigation of the Cardiovascular Effects of the 5HT(4) Receptor Selective Agonists, Velusetrag and TD-8954. Vascul Pharmacol. 58 (1-2), 150-156. doi:10.1016/j.vph.2012.11.002

Bernard, C. E., Gibbons, S. J., Mann, I. S., Froschauer, L., Parkman, H. P., Harbison, S., et al. (2014). Association of Low Numbers of CD206-Positive Cells with Loss of ICC in the Gastric Body of Patients with Diabetic Gastroparesis. Neurogastroenterol Motil. 26 (9), 1275-1284. doi:10.1111/nmo.12389

Bharucha, A. E., Daley, S. L., Low, P. A., Gibbons, S. J., Choi, K. M., Camilleri, M., et al. (2016). Effects of Hemin on Heme Oxygenase-1, Gastric Emptying, and Symptoms in Diabetic Gastroparesis. Neurogastroenterol Motil. 28 (11), 1731-1740. doi:10.1111/nmo.12874

Bortolotti, M., Cucchiara, S., Sarti, P., Brunelli, F., Mazza, M., Bagnato, F., et al. (1995). Comparison between the Effects of Neostigmine and Ranitidine on Interdigestive Gastroduodenal Motility of Patients with Gastroparesis. Digestion 56 (2), 96-99. doi:10.1159/000201227

Bortolotti, M., Mari, C., Brunelli, F., Sarti, P., and Miglioli, M. (1999). Effect of Intravenous Clarithromycin on Interdigestive Gastroduodenal Motility of Patients with Functional Dyspepsia and Helicobacter pylori Gastritis. Dig. Dis. Sci. 44 (12), 2439-2442. doi:10.1023/a:1026674719476

Bosmans, G., Shimizu Bassi, G., Florens, M., Gonzalez-Dominguez, E., Matteoli, G., and Boeckxstaens, G. E. (2017). Cholinergic Modulation of Type 2 Immune Responses. Front. Immunol. 8, 1873, 2017 . Dec 19. doi:10.3389/ fimmu.2017.01873

Bouras, E. P., Delgado-Aros, S., Camilleri, M., Castillo, E. J., Burton, D. D., Thomforde, G. M., et al. (2002). SPECT Imaging of the Stomach: Comparison with Barostat, and Effects of Sex, Age, Body Mass index, and Fundoplication. Single Photon Emission Computed Tomography. Gut 51 (6), 781-786. doi:10.1136/gut.51.6.781

Braden, B., Enghofer, M., Schaub, M., Usadel, K. H., Caspary, W. F., and Lembcke, B. (2002). Long-term Cisapride Treatment Improves Diabetic Gastroparesis but Not Glycaemic Control. Aliment. Pharmacol. Ther. 16 (7), 1341-1346. doi:10.1046/j.1365-2036.2002.01257.x

Camilleri, M., Iturrino, J., Bharucha, A. E., Burton, D., Shin, A., Jeong, I. D., et al. (2012). Performance Characteristics of Scintigraphic Measurement of Gastric Emptying of Solids in Healthy Participants. Neurogastroenterol Motil. 24 (12), 1076-e562. doi:10.1111/j.1365-2982.2012.01972.x

Camilleri, M., Lembo, A., McCallum, R., Tourkodimitris, S., Kemps, L., Miller, M. B., et al. (2020). Overall Safety of Relamorelin in Adults with Diabetic Gastroparesis: Analysis of Phase 2a and 2b Trial Data. Aliment. Pharmacol. Ther. 51 (11), 1139-1148. doi:10.1111/apt.15711

Camilleri, M., Malagelada, J. R., Abell, T. L., Brown, M. L., Hench, V., and Zinsmeister, A. R. (1989). Effect of Six Weeks of Treatment with Cisapride in Gastroparesis and Intestinal Pseudoobstruction. Gastroenterology 96 (3), 704-712. doi:10.1016/0016-5085(89)90893-7

Camilleri, M., McCallum, R. W., Tack, J., Spence, S. C., Gottesdiener, K., and Fiedorek, F. T. (2017). Efficacy and Safety of Relamorelin in Diabetics with Symptoms of Gastroparesis: a Randomized, Placebo-Controlled Study. Gastroenterology 153 (5), 1240-e2. doi:10.1053/j.gastro.2017.07.035
Camilleri, M., Papathanasopoulos, A., and Odunsi, S. T. (2009). Actions and Therapeutic Pathways of Ghrelin for Gastrointestinal Disorders. Nat. Rev. Gastroenterol. Hepatol. 6 (6), 343-352. doi:10.1038/nrgastro.2009.72

Camilleri, M., Parkman, H. P., Shafi, M. A., Abell, T. L., and Gerson, L. (2013). Clinical Guideline: Management of Gastroparesis. Am. J. Gastroenterol. 108 (1), 18-38. doi:10.1038/ajg.2012.373

Camilleri, M., and Sanders, K. M. (2020). Opiates, the Pylorus and Gastroparesis. Gastroenterology 159 (2), 414-421. doi:10.1053/j.gastro.2020.04.072

Carbone, F., Tack, J., and Hoffman, I. (2017). The Intragastric Pressure Measurement: A Novel Method to Assess Gastric Accommodation in Functional Dyspepsia Children. J. Pediatr. Gastroenterol. Nutr. 64 (6), 918-924. doi:10.1097/mpg.0000000000001386

Carbone, F., Van den Houte, K., Clevers, E., Andrews, C. N., Papathanasopoulos, A., Holvoet, L., et al. (2019). Prucalopride in Gastroparesis: a Randomized Placebo-Controlled Crossover Study. Am. J. Gastroenterol. 114 (8), 1265-1274. doi:10.14309/ajg.0000000000000304

Carlin, J. L., Lieberman, V. R., Dahal, A., Keefe, M. S., Xiao, C., Birznieks, G., et al. (2021). Efficacy and Safety of Tradipitant in Patients with Diabetic and Idiopathic Gastroparesis in a Randomized, Placebo-Controlled Trial. Gastroenterology 160 (1), 76-e4. doi:10.1053/j.gastro.2020.07.029

Catnach, S. M., and Fairclough, P. D. (1992). Erythromycin and the Gut. Gut 33 (3), 397-401. doi:10.1136/gut.33.3.397

Chai, N. L., Dong, L., Li, Z. F., Du, K. X., Wang, J. H., Yan, L. K., et al. (2003). Effects of Neurotrophins on Gastrointestinal Myoelectric Activities of Rats. World J. Gastroenterol. 9 (8), 1874-1877. doi:10.3748/wjg.v9.i8.187710.3748/ wjg.v9.i8.1874

Chapman, M. J., Jones, K. L., Almansa, C., Barnes, C. N., Nguyen, D., and Deane, A. M. (2021). Blinded, Double-Dummy, Parallel-Group, Phase 2a Randomized Clinical Trial to Evaluate the Efficacy and Safety of a Highly Selective 5Hydroxytryptamine Type 4 Receptor Agonist in Critically Ill Patients with Enteral Feeding Intolerance. J. Parenter. Enteral Nutr. 45 (1), 115-124. doi:10.1002/jpen.1732

Chedid, V., Brandler, J., Arndt, K., Vijayvargiya, P., Wang, X. J., Burton, D., et al. (2021). Randomised Study: Effects of the 5-HT4 Receptor Agonist Felcisetrag vs Placebo on Gut Transit in Patients with Gastroparesis. Aliment. Pharmacol. Ther. 53 (9), 1010-1020. doi:10.1111/apt.16304

Chedid, V., Brandler, J., Vijayvargiya, P., Park, S. Y., Szarka, L. A., and Camilleri, M. (2019). Characterization of Upper Gastrointestinal Symptoms, Gastric Motor Functions, and Associations in Patients with Diabetes at a Referral center. Am. J. Gastroenterol. 114 (1), 143-154. doi:10.1038/s41395-018-0234-1

Chedid, V., Halawi, H., Brandler, J., Burton, D., and Camilleri, M. (2019). Gastric Accommodation Measurements by Single Photon Emission Computed Tomography and Two-Dimensional Scintigraphy in Diabetic Patients with Upper Gastrointestinal Symptoms. Neurogastroenterol Motil. 31 (6), e13581. doi:10.1111/nmo.13581

Choi, K. M., Gibbons, S. J., Nguyen, T. V., Stoltz, G. J., Lurken, M. S., Ordog, T., et al. (2008). Heme Oxygenase-1 Protects Interstitial Cells of Cajal from Oxidative Stress and Reverses Diabetic Gastroparesis. Gastroenterology 135 (6), 2055-2064. doi:10.1053/j.gastro.2008.09.003

Cipriani, G., Gibbons, S. J., Miller, K. E., Yang, D. S., Terhaar, M. L., Eisenman, S. T., et al. (2018). Change in Populations of Macrophages Promotes Development of Delayed Gastric Emptying in Mice. Gastroenterology 154 (8), 2122-e12. doi:10.1053/j.gastro.2018.02.027

Coleski, R., Anderson, M. A., and Hasler, W. L. (2009). Factors Associated with Symptom Response to Pyloric Injection of Botulinum Toxin in a Large Series of Gastroparesis Patients. Dig. Dis. Sci. 54 (12), 2634-2642. doi:10.1007/s10620008-0660-9

Corinaldesi, R., Stanghellini, V., Raiti, C., Rea, E., Salgemini, R., and Barbara, L. (1987). Effect of Chronic Administration of Cisapride on Gastric Emptying of a Solid Meal and on Dyspeptic Symptoms in Patients with Idiopathic Gastroparesis. Gut 28 (3), 300-305. doi:10.1136/gut.28.3.300

Coulie, B., Szarka, L. A., Camilleri, M., Burton, D. D., McKinzie, S., Stambler, N., et al. (2000). Recombinant Human Neurotrophic Factors Accelerate Colonic Transit and Relieve Constipation in Humans. Gastroenterology 119 (1), 41-50. doi:10.1053/gast.2000.8553

Coulie, B., Tack, J., Peeters, T., and Janssens, J. (1998). Involvement of Two Different Pathways in the Motor Effects of Erythromycin on the Gastric Antrum in Humans. Gut 43 (3), 395-400. doi:10.1136/gut.43.3.395 
D’Errico, F., Goverse, G., Dai, Y., Wu, W., Stakenborg, M., Labeeuw, E., et al. (2018). Estrogen Receptor $\beta$ Controls Proliferation of Enteric Glia and Differentiation of Neurons in the Myenteric Plexus after Damage. Proc. Natl. Acad. Sci. U S A. 115 (22), 5798-5803. doi:10.1073/pnas.1720267115

De Maeyer, J. H., Prins, N. H., Schuurkes, J. A., and Lefebvre, R. A. (2006). Differential Effects of 5-hydroxytryptamine4 Receptor Agonists at Gastric versus Cardiac Receptors: an Operational Framework to Explain and Quantify Organ-specific Behavior. J. Pharmacol. Exp. Ther. 317 (3), 955-964. doi:10.1124/jpet.106.101329

De Schepper, S., Verheijden, S., Aguilera-Lizarraga, J., Viola, M. F., Boesmans, W., Stakenborg, N., et al. (2018). Self-maintaining Gut Macrophages Are Essential for Intestinal Homeostasis. Cell 175 (2), 400-e13. doi:10.1016/j.cell.2018.07.048

Dishy, V., Cohen Pour, M., Feldman, L., Naftali, T., Baumer, M., Efrati, S., et al. (2004). The Effect of Sildenafil on Gastric Emptying in Patients with End-Stage Renal Failure and Symptoms of Gastroparesis. Clin. Pharmacol. Ther. 76 (3), 281-286. doi:10.1016/j.clpt.2004.04.012

Friedenberg, F. K., Palit, A., Parkman, H. P., Hanlon, A., and Nelson, D. B. (2008). Botulinum Toxin A for the Treatment of Delayed Gastric Emptying. Am. J. Gastroenterol. 103 (2), 416-423. doi:10.1111/j.1572-0241.2007.01676.x

Grider, J. R., Piland, B. E., Gulick, M. A., and Qiao, L. Y. (2006). Brain-derived Neurotrophic Factor Augments Peristalsis by Augmenting 5-HT and Calcitonin Gene-Related Peptide Release. Gastroenterology 130 (3), 771-780. doi:10.1053/j.gastro.2005.12.026

Grover, M., Bernard, C. E., Pasricha, P. J., Lurken, M. S., Faussone-Pellegrini, M. S., Smyrk, T. C., et al. (2012). Clinical-histological Associations in Gastroparesis: Results from the Gastroparesis Clinical Research Consortium. Neurogastroenterol Motil. 24 (6), 531-e249. doi:10.1111/j.13652982.2012.01894.x

Grover, M., Bernard, C. E., Pasricha, P. J., Parkman, H. P., Gibbons, S. J., Tonascia, J., et al. (2017). Diabetic and Idiopathic Gastroparesis Is Associated with Loss of CD206-Positive Macrophages in the Gastric Antrum. Neurogastroenterol Motil. 29 (6). doi:10.1111/nmo.13018

Grover, M., Farrugia, G., Lurken, M. S., Bernard, C. E., Faussone-Pellegrini, M. S., Smyrk, T. C., et al. (2011). Cellular Changes in Diabetic and Idiopathic Gastroparesis. Gastroenterology 140 (5), 1575-e8. doi:10.1053/ j.gastro.2011.01.046

Halawi, H., Vijayvargiya, P., Busciglio, I., Oduyebo, I., Khemani, D., Ryks, M., et al. (2018). Effects of Naloxegol on Whole Gut Transit in Opioid-Naïve Healthy Subjects Receiving Codeine: A Randomized, Controlled Trial. Neurogastroenterol Motil. 30 (5), e13298. doi:10.1111/nmo.13298

Hasler, W. L., Wilson, L. A., Nguyen, L. A., Snape, W. J., Abell, T. L., Koch, K. L., et al. (2019). Opioid Use and Potency Are Associated with Clinical Features, Quality of Life, and Use of Resources in Patients with Gastroparesis. Clin. Gastroenterol. Hepatol. 17 (7), 1285-e1. doi:10.1016/j.cgh.2018.10.013e1

Herring, B. P., Hoggatt, A. M., Gupta, A., Griffith, S., Nakeeb, A., Choi, J. N., et al. (2018). Idiopathic Gastroparesis Is Associated with Specific Transcriptional Changes in the Gastric Muscularis Externa. Neurogastroenterol Motil. 30 (4), e13230. doi:10.1111/nmo.13230

Jacob, D., Busciglio, I., Burton, D., Halawi, H., Oduyebo, I., Rhoten, D., et al. (2017). Effects of NK1 Receptors on Gastric Motor Functions and Satiation in Healthy Humans: Results from a Controlled Trial with the NK1 Antagonist Aprepitant. Am. J. Physiol. Gastrointest. Liver Physiol. 313 (05), G505-G10. doi:10.1152/ ajpgi.00197.2017

Janssens, J., Peeters, T. L., Vantrappen, G., Tack, J., Urbain, J. L., De Roo, M., et al. (1990). Improvement of Gastric Emptying in Diabetic Gastroparesis by Erythromycin. Preliminary Studies. N. Engl. J. Med. 322 (15), 1028-1031. doi:10.1056/nejm199004123221502

Kawamura, E., Enomoto, M., Kotani, K., Hagihara, A., Fujii, H., Kobayashi, S., et al. (2012). Effect of Mosapride Citrate on Gastric Emptying in Interferon-Induced Gastroparesis. Dig. Dis. Sci. 57 (6), 1510-1516. doi:10.1007/s10620-012-2085-8

Kulkarni, S., Micci, M. A., Leser, J., Shin, C., Tang, S. C., Fu, Y. Y., et al. (2017). Adult Enteric Nervous System in Health Is Maintained by a Dynamic Balance between Neuronal Apoptosis and Neurogenesis. Proc. Natl. Acad. Sci. U S A. 114 (18), E3709-E3718. doi:10.1073/pnas.1619406114

Kuo, B., Barnes, C. N., Nguyen, D. D., Shaywitz, D., Grimaldi, M., Renzulli, C., et al. (2021). Velusetrag Accelerates Gastric Emptying in Subjects with Gastroparesis: a Multicentre, Double-Blind, Randomised, Placebo-Controlled, Phase 2 Study. Aliment. Pharmacol. Ther. 53 (10), 1090-1097. doi:10.1111/apt.16344
Kuo, B., Scimia, C., Dukes, G., Zhang, W., Gupta, S., Chen, C., et al. (2021). Randomised Clinical Trial: Safety, Pharmacokinetics and Pharmacodynamics of Trazpiroben (TAK-906), a Dopamine D 2/D 3 Receptor Antagonist, in Patients with Gastroparesis. Aliment. Pharmacol. Ther. 54 (3), 267-280. doi:10.1111/apt.16451

Kusunoki, H., Haruma, K., Manabe, N., Imamura, H., Kamada, T., Shiotani, A., et al. (2012). Therapeutic Efficacy of Acotiamide in Patients with Functional Dyspepsia Based on Enhanced Postprandial Gastric Accommodation and Emptying: Randomized Controlled Study Evaluation by Real-Time Ultrasonography. Neurogastroenterol Motil. 24 (6), 540-541. doi:10.1111/ j.1365-2982.2012.01897.x

Larson, J. M., Tavakkoli, A., Drane, W. E., Toskes, P. P., and Moshiree, B. (2010). Advantages of Azithromycin over Erythromycin in Improving the Gastric Emptying Half-Time in Adult Patients with Gastroparesis. J. Neurogastroenterol Motil. 16 (4), 407-413. doi:10.5056/jnm.2010.16.4.407

Lembo, A., Camilleri, M., McCallum, R., Sastre, R., Breton, C., Spence, S., et al. (2016). Relamorelin Reduces Vomiting Frequency and Severity and Accelerates Gastric Emptying in Adults with Diabetic Gastroparesis. Gastroenterology 151 (1), 87-e6. doi:10.1053/j.gastro.2016.03.038

Liau, S. S., Camilleri, M., Kim, D. Y., Stephens, D., Burton, D. D., and O'Connor, M. K. (2001). Pharmacological Modulation of Human Gastric Volumes Demonstrated Noninvasively Using SPECT Imaging. Neurogastroenterol Motil. 13 (6), 533-542. doi:10.1046/j.1365-2982.2001.00287.x

Lucey, M. A., Patil, V., Girling, K., Jacques, T., and O'Leary, M. (2003). Does Neostigmine Increase Gastric Emptying in the Critically Ill?-Rresults of a Pilot Study. Crit. Care Resusc 5 (1), 14-19.

Manini, M. L., Camilleri, M., Grothe, R., and Di Lorenzo, C. (2017). Application of Pyridostigmine in Pediatric Gastrointestinal Motility Disorders: a Case Series. Paediatr. Drugs 20 (2), 173-180. doi:10.1007/s40272-017-0277-6

Matsueda, K., Hongo, M., Tack, J., Saito, Y., and Kato, H. (2012). A PlaceboControlled Trial of Acotiamide for Meal-Related Symptoms of Functional Dyspepsia. Gut 61 (6), 821-828. doi:10.1136/gutjnl-2011-301454

Matteoli, G., Gomez-Pinilla, P. J., Nemethova, A., Di Giovangiulio, M., Cailotto, C., van Bree, S. H., et al. (2013). A Distinct Vagal Anti-inflammatory Pathway Modulates Intestinal Muscularis Resident Macrophages Independent of the Spleen. Gut 63 (6), 938-948. doi:10.1136/gutjnl-2013-304676

Mearin, F., Camilleri, M., and Malagelada, J. R. (1986). Pyloric Dysfunction in Diabetics with Recurrent Nausea and Vomiting. Gastroenterology 90 (6) 1919-1925. doi:10.1016/0016-5085(86)90262-3

Narducci, F., Bassotti, G., Granata, M. T., Gaburri, M., Farroni, F., Palumbo, R., et al. (1986). Functional Dyspepsia and Chronic Idiopathic Gastric Stasis. Role of Endogenous Opiates. Arch. Intern. Med. 146 (4), 716-720. doi:10.1001/ archinte.1986.00360160140019

Nelson, A. D., Camilleri, M., Acosta, A., Busciglio, I., Linker Nord, S., Boldingh, A., et al. (2016). Effects of Ghrelin Receptor Agonist, Relamorelin, on Gastric Motor Functions and Satiation in Healthy Volunteers. Neurogastroenterol Motil. 28 (11), 1705-1713. doi:10.1111/nmo.12870

Orthey, P., Dadparvar, S., Parkman, H. P., and Maurer, A. H. (2018). Enhanced Gastric Emptying Scintigraphy to Assess Fundic Accommodation Using Intragastric Meal Distribution and Antral Contractility. J. Nucl. Med. Technol. 47 (2), 138-143. doi:10.2967/jnmt.118.215566

Orthey, P., Yu, D., Van Natta, M. L., Ramsey, F. V., Diaz, J. R., Bennett, P. A., et al. (2018). Intragastric Meal Distribution during Gastric Emptying Scintigraphy for Assessment of Fundic Accommodation: Correlation with Symptoms of Gastroparesis. J. Nucl. Med. 59 (4), 691-697. doi:10.2967/jnumed.117.197053

Park, S. Y., Acosta, A., Camilleri, M., Burton, D., Harmsen, W. S., Fox, J., et al. (2017). Gastric Motor Dysfunction in Patients with Functional Gastroduodenal Symptoms. Am. J. Gastroenterol. 112 (11), 1689-1699. doi:10.1038/ajg.2017.264

Parkman, H. P., Pagano, A. P., Vozzelli, M. A., and Ryan, J. P. (1995). Gastrokinetic Effects of Erythromycin: Myogenic and Neurogenic Mechanisms of Action in Rabbit Stomach. Am. J. Physiol. 269 (3), G418-G426. doi:10.1152/ ajpgi.1995.269.3.g418

Pasricha, P. J., Yates, K. P., Sarosiek, I., McCallum, R. W., Abell, T. L., Koch, K. L., et al. (2018). Aprepitant Has Mixed Effects on Nausea and Reduces Other Symptoms in Patients with Gastroparesis and Related Disorders. Gastroenterology 154 (01), 65-e11. doi:10.1053/j.gastro.2017.08.033

Patterson, D., Abell, T., Rothstein, R., Koch, K., and Barnett, J. (1999). A DoubleBlind Multicenter Comparison of Domperidone and Metoclopramide in the 
Treatment of Diabetic Patients with Symptoms of Gastroparesis. Am. J. Gastroenterol. 94 (5), 1230-1234. doi:10.1111/j.1572-0241.1999.00456.x

Peeters, T. L. (2003). Central and Peripheral Mechanisms by Which Ghrelin Regulates Gut Motility. J. Physiol. Pharmacol. 54 Suppl 4 (4), 95-103.

Portincasa, P., Mearin, F., Robert, M., Plazas, M. J., Mas, M., and Heras, J. (2009). Efficacy and Tolerability of Cinitapride in the Treatment of Functional Dyspepsia and Delayed Gastric Emptying. Gastroenterol. Hepatol. 32 (10), 669-676. doi:10.1016/j.gastrohep.2009.06.013

Ray, W. A., Murray, K. T., Meredith, S., Narasimhulu, S. S., Hall, K., and Stein, C. M. (2004). Oral Erythromycin and the Risk of Sudden Death from Cardiac Causes. N. Engl. J. Med. 351 (11), 1089-1096. doi:10.1056/nejmoa040582

Richards, R. D., Davenport, K., and McCallum, R. W. (1993). The Treatment of Idiopathic and Diabetic Gastroparesis with Acute Intravenous and Chronic Oral Erythromycin. Am. J. Gastroenterol. 88 (2), 203-207.

Richards, R. D., Valenzuela, G. A., Davenport, K. G., Fisher, K. L., and McCallum, R. W. (1993). Objective and Subjective Results of a Randomized, Double-Blind, Placebo-Controlled Trial Using Cisapride to Treat Gastroparesis. Dig. Dis. Sci. 38 (5), 811-816. doi:10.1007/bf01295905

Shin, A., Camilleri, M., Busciglio, I., Burton, D., Smith, S. A., Vella, A., et al. (2013). The Ghrelin Agonist RM-131 Accelerates Gastric Emptying of Solids and Reduces Symptoms in Patients with Type 1 Diabetes Mellitus. Clin. Gastroenterol. Hepatol. 11 (11), 1453-e4. doi:10.1016/j.cgh.2013.04.019

Shin, A., Camilleri, M., Busciglio, I., Burton, D., Stoner, E., Noonan, P., et al. (2013). Randomized Controlled Phase Ib Study of Ghrelin Agonist, RM-131, in Type 2 Diabetic Women with Delayed Gastric Emptying: Pharmacokinetics and Pharmacodynamics. Diabetes Care 36 (1), 41-48. doi:10.2337/dc12-1128

Stakenborg, N., Labeeuw, E., Gomez-Pinilla, P. J., De Schepper, S., Aerts, R., Goverse, G., et al. (2019). Preoperative Administration of the 5-HT4 Receptor Agonist Prucalopride Reduces Intestinal Inflammation and Shortens Postoperative Ileus via Cholinergic Enteric Neurons. Gut 68 (8), 1406-1416. doi:10.1136/gutjnl-2018-317263

Surrenti, E., Camilleri, M., Kammer, P. P., Prather, C. M., Schei, A. J., and Hanson, R. B. (1996). Antral Axial Forces Postprandially and after Erythromycin in Organic and Functional Dysmotilities. Dig. Dis. Sci. 41 (4), 697-704. doi:10.1007/bf02213125

Szarka, L. A., Camilleri, M., Vella, A., Burton, D., Baxter, K., Simonson, J., et al. (2008). A Stable Isotope Breath Test with a Standard Meal for Abnormal Gastric Emptying of Solids in the Clinic and in Research. Clin. Gastroenterol. Hepatol. 6 (6), 635-e1. doi:10.1016/j.cgh.2008.01.009e1

Tack, J., Caenepeel, P., Piessevaux, H., Cuomo, R., and Janssens, J. (2003). Assessment of Meal Induced Gastric Accommodation by a Satiety Drinking Test in Health and in Severe Functional Dyspepsia. Gut 52 (9), 1271-1277. doi:10.1136/gut.52.9.1271

Tack, J., Camilleri, M., Chang, L., Chey, W. D., Galligan, J. J., Lacy, B. E., et al. (2012). Systematic Review: Cardiovascular Safety Profile of 5-HT(4) Agonists Developed for Gastrointestinal Disorders. Aliment. Pharmacol. Ther. 35 (7), 745-767. doi:10.1111/j.1365-2036.2012.05011.x

Tack, J., Depoortere, I., Bisschops, R., Delporte, C., Coulie, B., Meulemans, A., et al. (2006). Influence of Ghrelin on Interdigestive Gastrointestinal Motility in Humans. Gut 55 (3), 327-333. doi:10.1136/gut.2004.060426

Tack, J., Janssen, P., Bisschops, R., Vos, R., Phillips, T., and Tougas, G. (2010). Influence of Tegaserod on Proximal Gastric Tone and on the Perception of Gastric Distention in Functional Dyspepsia. Neurogastroenterol Motil. 23 (2), e32-9. doi:10.1111/j.1365-2982.2010.01613.x

Tack, J., Piessevaux, H., Coulie, B., Caenepeel, P., and Janssens, J. (1998). Role of Impaired Gastric Accommodation to a Meal in Functional Dyspepsia. Gastroenterology 115 (6), 1346-1352. doi:10.1016/s0016-5085(98)70012-5
Thielemans, L., Depoortere, I., Perret, J., Robberecht, P., Liu, Y., Thijs, T., et al. (2005). Desensitization of the Human Motilin Receptor by Motilides. J. Pharmacol. Exp. Ther. 313 (3), 1397-1405. doi:10.1124/jpet.104.081497

Tonini, M., Cipollina, L., Poluzzi, E., Crema, F., Corazza, G. R., and De Ponti, F. (2004). Review Article: Clinical Implications of Enteric and central D2 Receptor Blockade by Antidopaminergic Gastrointestinal Prokinetics. Aliment. Pharmacol. Ther. 19 (4), 379-390. doi:10.1111/j.1365-2036.2004.01867.x

Vakil, N., Laine, L., Talley, N. J., Zakko, S. F., Tack, J., Chey, W. D., et al. (2008). Tegaserod Treatment for Dysmotility-like Functional Dyspepsia: Results of Two Randomized, Controlled Trials. Am. J. Gastroenterol. 103 (8), 1906-1919. doi:10.1111/j.1572-0241.2008.01953.x

Van der Ploeg, L., Laken, H., Sharma, S., Datta, R., Halem, H., Dong, J., et al. (2014). Preclinical Gastrointestinal Prokinetic Efficacy and Endocrine Effects of the Ghrelin Mimetic RM-131. Life Sci. 109 (1), 20-29. doi:10.1016/j.lfs.2014.06.003

Vijayvargiya, P., Camilleri, M., Chedid, V., Mandawat, A., Erwin, P. J., and Murad, M. H. (2019). Effects of Promotility Agents on Gastric Emptying and Symptoms: a Systematic Review and Meta-Analysis. Gastroenterology 156 (6), 1650-1660. doi:10.1053/j.gastro.2019.01.249

Vosoughi, K., Ichkhanian, Y., Jacques, J., Aadam, A. A., Benias, P. C., Law, R., et al. (2020). Role of Endoscopic Functional Luminal Imaging Probe in Predicting the Outcome of Gastric Peroral Endoscopic Pyloromyotomy (With Video). Gastrointest. Endosc. 91 (6), 1289-1299. doi:10.1016/ j.gie.2020.01.044

Wang, X. J., Burton, D. D., Breen-Lyles, M., and Camilleri, M. (2021). Gastric Accommodation Influences Proximal Gastric and Total Gastric Emptying in Concurrent Measurements Conducted in Healthy Volunteers. Am. J. Physiol. Gastrointest. Liver Physiol. 320 (5), G759-G767. doi:10.1152/ ajpgi.00008.2021

Watkins, C. C., Sawa, A., Jaffrey, S., Blackshaw, S., Barrow, R. K., Snyder, S. H., et al. (2000). Insulin Restores Neuronal Nitric Oxide Synthase Expression and Function that Is Lost in Diabetic Gastropathy. J. Clin. Invest. 106 (3), 803-884. doi:10.1172/JCI8273

Wong, B. S., Rao, A. S., Camilleri, M., Manabe, N., McKinzie, S., Busciglio, I., et al. (2010). The Effects of Methylnaltrexone Alone and in Combination with Acutely Administered Codeine on Gastrointestinal and Colonic Transit in Health. Aliment. Pharmacol. Ther. 32 (7), 884-893. doi:10.1111/j.13652036.2010.04422.x

Conflict of Interest: $\mathrm{MC}$ is an advisor to Takeda and Allergan, with the consulting fees paid to his employer, Mayo Clinic.

The remaining author declares that the research was conducted in the absence of any commercial or financial relationships that could be construed as a potential conflict of interest.

Publisher's Note: All claims expressed in this article are solely those of the authors and do not necessarily represent those of their affiliated organizations, or those of the publisher, the editors and the reviewers. Any product that may be evaluated in this article, or claim that may be made by its manufacturer, is not guaranteed or endorsed by the publisher.

Copyright $\odot 2021$ Camilleri and Atieh. This is an open-access article distributed under the terms of the Creative Commons Attribution License (CC BY). The use, distribution or reproduction in other forums is permitted, provided the original author(s) and the copyright owner(s) are credited and that the original publication in this journal is cited, in accordance with accepted academic practice. No use, distribution or reproduction is permitted which does not comply with these terms. 